\title{
The BoC-BoE Sovereign Default Database Revisited: What's New in 2018?
}

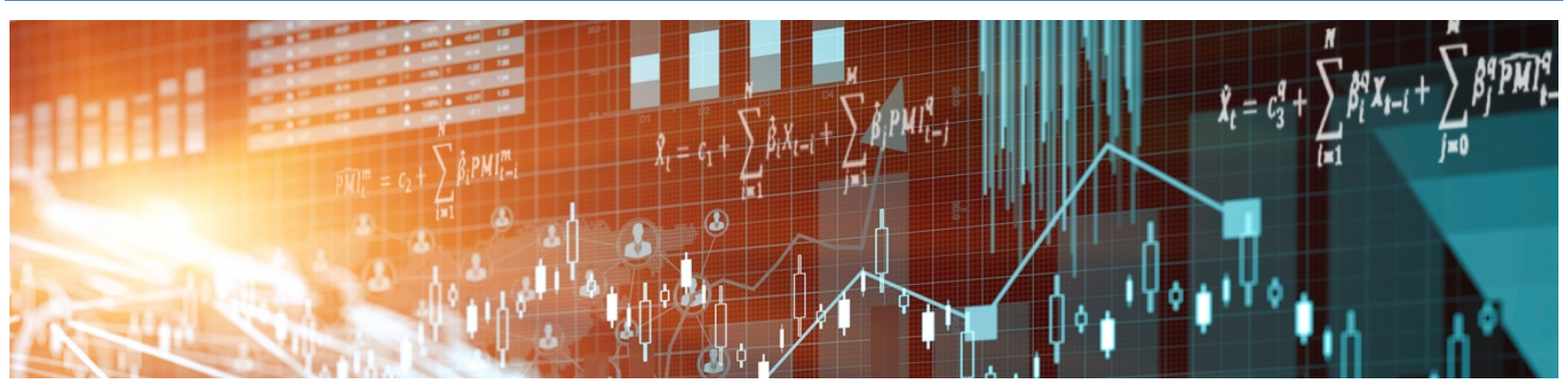

by David Beers and Jamshid Mavalwalla 
Bank of Canada Staff Working Paper 2018-30

July 2018

\title{
The BoC-BoE Sovereign Default Database Revisited: What's New in 2018?
}

\author{
by
}

\author{
David Beers $^{1}$ and Jamshid Mavalwalla ${ }^{2}$ \\ ${ }^{1}$ Special Advisor, International Directorate \\ Bank of England \\ London, United Kingdom EC2R 8AH \\ David.Beers@bankofengland.co.uk \\ ${ }^{2}$ Funds Management and Banking Department \\ Bank of Canada \\ Ottawa, Ontario, Canada K1A 0G9 \\ imavalwalla@bankofcanada.ca
}




\section{Acknowledgements}

We are grateful to Allan Crawford, Grahame Johnson, Philippe Muller, Peter Youngman, Carolyn A. Wilkins, John Chambers, Stuart Culverhouse, Archil Imnaishvili, Marc Joffe, Mark Joy, and James McCormack for their helpful comments and suggestions, to Christian Suter for sharing with us previously unpublished data he compiled with Volker Bornschier and Ulrich Pfister in 1986, and to Jean-Sébastien Nadeau for his many contributions to this and earlier versions of the technical report and the database. We thank Norman Yeung and Isabelle Brazeau for their able technical assistance, and Glen Keenleyside, Meredith Fraser-Ohman and Carole Hubbard for their excellent editorial assistance. Any remaining errors are the sole responsibility of the authors. 


\begin{abstract}
Until recently, there have been few efforts to systematically measure and aggregate the nominal value of the different types of sovereign government debt in default. To help fill this gap, the Bank of Canada's Credit Rating Assessment Group (CRAG) has developed a comprehensive database of sovereign defaults posted on the Bank of Canada's website that now is updated in partnership with the Bank of England. Our database draws on previously published data sets compiled by various public and private sector sources. It combines elements of these, together with new information, to develop estimates of stocks of government obligations in default, including bonds and other marketable securities, bank loans, and official loans in default, valued in US dollars, for the years 1960 to 2017 on both a country-by-country and a global basis. This update of CRAG's database, and subsequent updates, will be useful to researchers analyzing the economic and financial effects of individual sovereign defaults and, importantly, the impact on global financial stability of episodes involving multiple sovereign defaults.

Bank topics: Debt management; Development economics; Financial stability; International financial markets

JEL codes: F34, G10, G14, G15
\end{abstract}

\title{
Résumé
}

Jusqu'à tout récemment, peu d'efforts étaient consacrés à l'évaluation systématique des différents types de défauts souverains ainsi qu'au calcul de la valeur nominale globale des engagements qu'ils représentent. Afin de remédier à cette lacune, le Groupe chargé de la notation du crédit de la Banque du Canada a développé une base de données exhaustive de défauts souverains, qui se trouve sur le site Internet de la Banque et qui sera dorénavant mise à jour en partenariat avec la Banque d’Angleterre. Cette base repose sur l'exploitation et la compilation de données préalablement publiées par diverses sources, publiques et privées. De plus, elle contient de nouvelles données qui, conjuguées aux autres sources, permettent d'estimer le montant total des prêts bancaires, des obligations et autres titres négociables, de même que des prêts officiels en situation de défaut, tous exprimés en dollars américains, pour la période allant de 1960 à 2017. Cette information est présentée à la fois pays par pays, et de manière agrégée, c'est-à-dire à l'échelle mondiale. La base de données actualisée du Groupe chargé de la notation du crédit, et ses mises à jour ultérieures, sera utile aux chercheurs souhaitant analyser les effets économiques et financiers de la défaillance d’emprunteurs souverains spécifiques, ainsi que - dimension importante - l'incidence sur la stabilité financière mondiale de multiples défauts souverains.

Sujets : Gestion de la dette; Économie du développement; Stabilité financière; Marchés financiers internationaux Codes JEL : F34, G10, G14, G15 


\section{Non-Technical Summary}

Responding to the fragmented public information available on sovereign defaults, the Bank of Canada's Credit Rating Assessment Group (CRAG) launched a unique database in 2014, now updated annually in partnership with the Bank of England. It provides estimates of government debt in default, including obligations owed to official and private creditors, valued in US dollars for the 1960-2017 period, by country and debt type and aggregated globally. This data set and our related commentary on historical trends, which are updated annually, give researchers a more comprehensive picture than previously available to support their analysis of the economic and financial effects of individual defaults and, importantly, of the impact on global financial stability of defaults by multiple sovereigns.

\section{What we do}

As there is no internationally agreed definition of the characteristics of sovereign defaults, we first outline our criteria for determining when a default occurs. We then describe the main components of the database, and how they are compiled for the main creditor categories - the International Monetary Fund, the International Bank for Reconstruction and Development, the Paris Club, other official creditors, foreign currency bank loans, foreign currency bonds, other foreign currency private creditor loans, and local currency debt.

We also note that due to challenges in documenting when sovereigns default and the amounts of debt involved, some of our country data is provisional. We explain how we develop these estimates, which may be revised in future database updates as additional information becomes available. The paper concludes with a commentary highlighting major trends in the historical data, while an appendix provides country-by-country information on our data sources.

\section{What we find}

Since 1960, 145 governments have defaulted on their obligations-well over half the current universe of 214 sovereigns.

Defaults had the biggest global impact in the 1980s, peaking at 6.2 per cent of world public debt in 1990 . The scale of defaults has fallen substantially since then - even in 2012-13 when euro area sovereigns were involved — to an estimated 0.3 per cent of world public debt last year.

Our evidence offers a more nuanced view of earlier research on sovereign default "clusters"-spikes in the number of defaults followed by sharp declines-once debt owed to official creditors is taken into account. This is because such defaults often take longer to resolve than defaults involving private creditors. The US dollar amounts can be low in absolute terms, but the number of low-income sovereigns involved can persist for long periods.

Defaults involving the Paris Club group of official creditors are declining in importance, but those involving other bilateral official creditors are growing.

Sovereign defaults on local currency debt are more common than sometimes supposed, involving 31 sovereigns since 1960. The majority resulted from the exchange of old central bank currency for new on confiscatory terms. The rest involved overdue debt service; restructurings of maturities and/or write-downs; reductions in real interest rate coupons on inflation-linked debt; conversions of discounted principal into foreign currency debt; and new taxes targeting local currency debt service.

Looking ahead, we conclude that defaults are likely to pick up again over the next decade, given growing public debt burdens in many advanced and emerging-market countries. At the same time, with rising crossborder investment in domestic debt markets, defaults on local currency debt could become as common as defaults on foreign currency bonds. 


\section{Introduction}

Government debt defaults are a recurring feature of public finance. These defaults have typically involved low-income and emerging-market economies, although recent cases include advanced-economy sovereigns. As a result, there is a prolific literature analyzing various aspects of sovereign debt crises - notably the political and economic factors that drive defaults, their domestic economic and financial effects and the global impact of episodes where multiple defaults are involved. ${ }^{1}$

Even so, comprehensive data on sovereign defaults have been hard to come by. This reflects a number of factors. An important reason is that there is no single internationally recognized definition of what constitutes a sovereign default. As a result, standards used by government borrowers and their creditors to report defaults, if they report at all, differ, and information on the various types of defaulted debt must be mined from different sources. The Bank of Canada's Credit Rating Assessment Group (CRAG) database-now compiled in partnership with the Bank of England-helps fill these gaps through the compilation of a comprehensive country-by-country and global data set of government debt in default that applies a common standard for determining when defaults occur.

This report is organized as follows. We start by proposing a definition of when a sovereign default has occurred. We next describe the main components of the CRAG database. We highlight the sources we used to compile the data and, where applicable, the methods employed to develop estimates. We also score the reliability of default data for each country. We then provide a commentary looking at historical trends in the default data, including a section focusing on local currency defaults, which can deepen our understanding of the impact on global financial stability of individual and multiple cases of sovereign defaults. A final section offers some conclusions. An appendix provides additional information on the sources used for the country-by-country and aggregate data.

\section{Determining Sovereign Defaults}

Like other types of debt, sovereign debt - the term commonly used to denote debt issued by national governments and certain fiscally autonomous territories-is a contractual obligation.

\footnotetext{
${ }^{1}$ For a comprehensive overview, see Tomz and Wright (2012).
} 
A failure to meet this contractual obligation to pay interest or principal in full on the due date provides one clear-cut example of a sovereign default. Another example is a failure by a government to honour debt it has lawfully guaranteed where there are clear provisions for the guarantor to make timely payment. That said, because government responses to financial distress can take many forms, sovereign defaults are often not so explicit. In some cases, we can conclude that, even without an actual interruption of debt service, a default has effectively occurred because actions by the sovereign result in economic losses by creditors. Such losses can vary widely.

Consistent with much of the literature on sovereign defaults (Cruces and Trebesch 2011), and the practice of credit-rating agencies (Beers and Chambers 2006; Tudela et al. 2011), ${ }^{2}$ we consider a default has occurred when debt service is not paid on the due date or within a specified grace period, when payments are not made within the time frame specified under a guarantee, or, absent an outright payment default, in any of the following circumstances where creditors incur material economic losses on the sovereign debt they hold:

- agreements between governments and creditors that reduce interest rates and/or extend maturities on outstanding debt

- government exchange offers to creditors where existing debt is swapped for new debt on less-economic terms

- government purchases of debt at substantial discounts to par

- government redenomination of foreign currency debt into new local currency obligations on less-economic terms

- swaps of sovereign debt for equity (usually relating to privatization programs) on lesseconomic terms

- retrospective taxes targeting sovereign debt service payments

- conversion of central bank notes into new currency of less-than-equivalent face value

\section{Features of the CRAG Sovereign Default Database}

CRAG's sovereign database—-posted on the Bank's website at

\footnotetext{
${ }^{2}$ Sovereign ratings assigned by credit-rating agencies typically assess the likelihood of timely payment of government and central bank bills, notes, bonds and bank loans, not the likelihood of timely payment of loans contracted from the International Monetary Fund, the multilateral lending institutions and other official creditors.
} 
http://www.bankofcanada.ca/wp-content/uploads/2017/07/crag-database-update-13-0718.xlsx - tabulates data on debt owed to official and private creditors for all sovereign defaults that we have identified between the years 1960 and 2017. ${ }^{3}$ For each year, we compile the data by type of creditor on both a country-by-country and an aggregated basis to show global totals. All country and global data on debt in default are expressed in nominal US dollars. Sovereigns in default at any point during the year, together with the amounts of debt affected, are shown in the annual totals. Anticipating future updates, the database also shows the date of the most recent revision.

In the June 2018 update, our first estimate puts total debt in default at US\$216.4 billion in 2017, fractionally lower than the revised total of US\$218.8 billion in 2016. Within last year's global total, the value of foreign currency defaulted bonds showed the largest increaseUS\$3.3 billion, to an estimated US\$77.8 billion—due to Puerto Rico’s escalating default that began in 2015, and new defaults by Belize, the Republic of Congo, El Salvador, Mozambique and Venezuela. ${ }^{4}$ These were offset in part by the resolution of Argentina's bond default in 2016, which dropped out of last year's total. The value of defaulted loans due to other official creditors also rose, mostly reflecting further growth in arrears by existing debtors. By contrast, Paris Club loans and local currency debt in default declined, while the values of defaulted debt in other creditor categories were little changed.

The other main changes in the June 2018 update include the following:

- enhanced coverage, with additional default data for 1960-69

- revisions of country and aggregate default data for 1970-2016, most notably for Sudan where, based on IMF data, we raised our estimate of the value of defaulted debt in 2016 by more than US\$20 billion and made comparable revisions to the values in earlier years ${ }^{5}$

- inclusion of a new special topic section comparing the frequency of local currency defaults in 1960-2017 with defaults on foreign currency bank loans and bonds

\footnotetext{
${ }^{3}$ The CRAG database is distinct from and complements the data sets measuring the nominal value of sovereign debt restructuring agreements and creditor losses involving private creditors and Paris Club official creditors published by Cruces and Trebesch (2011) and Das, Papaioannou and Trebesch (2012), respectively.

${ }^{4}$ Since Puerto Rico forms part of the United States' monetary union, for this analysis we consider its US-dollar bonds to be foreign currency debt.

${ }^{5}$ Our previous estimates for Sudan were based in part on World DataBank data on official creditor arrears provided by the government, while the IMF estimates incorporate information based on a reconciliation of both creditor and debtor data.
} 
Within the country and global totals, debt in one or more of the following creditor subcategories is included:

- International Monetary Fund (IMF)

- International Bank for Reconstruction and Development (IBRD, part of the World Bank Group)

- Paris Club

- other official creditors

- private creditors

- foreign currency bank loans

- foreign currency bonds

- local currency debt

In addition to the country-by-country components, in most cases the database contains the following aggregate data for the period starting in 1960 and ending in 2017:

- total debt in default (in nominal US dollars)

- total debt in default by creditor type (in nominal US dollars)

- total debt in default by debtor type (in nominal US dollars)

- number of sovereign governments

- number of sovereign governments in default

- outstanding Paris Club debt (in nominal US dollars)

- global general government or public debt (in nominal US dollars)

- global gross domestic product (GDP) (in nominal US dollars)

\section{Data Sources and Data Estimation}

To construct the CRAG database, we utilized data published by the Asian Development Bank (2018 and earlier years); the IMF (2018 and earlier years); the Paris Club (2018); the World DataBank (2018); the IBRD’s annual financial statements (2017 and earlier years); Tweedie, Hagan and Tiwari (2012); Das, Papaioannou and Trebesch (2012); Cruces and Trebesch (2011); Tudela et al. (2011); Beers and Chambers (2006); and Suter (1992). We combined elements of these data sets, together with information from national governments and other sources, to develop our estimates of stocks of bank loans, bonds and other marketable securities, other private creditor claims, and IMF, IBRD, Paris Club and other official loans 
in default for the years 1960 through 2017. An appendix provides a country-by-country list of sources.

It is important to highlight that some of our country data is, in fact, estimated. As Cruces and Trebesch (2011) and others have noted, documenting which sovereigns have defaulted, the time frame of such defaults and the amounts of debt affected can be challenging. This is particularly true for local currency defaults, which often are not acknowledged as such by the governments involved and which have been little studied in the literature. Even in betterdocumented cases where defaults are resolved through a formal debt-restructuring process, different sources can, at times, provide contradictory information.

Consequently, while we have relied on sources we consider credible, our database of sovereign defaults may not be exhaustive. We may have overlooked some defaults, and we may ultimately revise our estimates of the US-dollar amounts of debt in default. As we gain additional information on defaults, we will include the data in future database updates. Any errors in the identification and estimation processes employed are, of course, the sole responsibility of the authors.

Below we outline how we estimate values of different types of defaulted debt:

IMF lending. This category refers to IMF loans to member governments and obligations to pay IMF membership quotas. The IMF does not report late payments as defaults because it is a preferred creditor - meaning that generally it is paid ahead of other types of creditors and, when payments are late, expects ultimately to be repaid. Even so, there are cases (in the 1960s) where IMF loans were reprofiled in tandem with restructurings of other debts owed by sovereigns and (throughout the 1960-2017 period) where payment arrears have persisted for extended periods. In addition, the IMF has written off some loans to countries receiving official debt relief under the Multilateral Debt Relief Initiative (MDRI). Our sources on payment arrears and reschedulings are IMF annual reports, Article IV reports on member countries, use of IMF credit as reported in the IMF's International Financial Statistics, and reports by the IMF on cases of "protracted arrears.” Utilizing these data and information on loan charges, we compute cumulative interest arrears and charges and apply them to the principal amount of loans and overdue quota amounts reported as being in arrears for at least 
six months. ${ }^{6}$ Since IMF lending is denominated in special drawing rights, we use applicable end-of-period exchange rates to convert amounts of estimated defaulted loans into US dollars. Because MDRI-related loan write-offs are funded by donor governments and do not impair the IMF’s balance sheet, they form one component of the other official creditor data category discussed below.

MLI lending. This category refers to loans by multilateral lending institutions (MLIs) to member governments. Many MLIs — all owned or controlled by groups of governmentshave preferred creditor status, but like the IMF periodically have experienced late payments on their loans. Reporting practices on such loans vary, although the World Bank (IBRD) and the largest regional development banks publish reasonably comprehensive data on arrears of principal and interest when they persist for six months or more. We publish separate IBRD country data on its loans in arrears for the years 1985-2017. In the global totals, we also show the value of loans in arrears for the years 1980-84, a period when the IBRD did not identify the relevant individual countries. Our source is the IBRD’s annual financial statements. $^{7}$ Apart from the IBRD data just noted, MLI lending, including MDRI-related write-offs, is one component of our proxy for other official debt in default described below.

Paris Club lending. This category refers to loans extended by the Paris Club, an informal group of bilateral official lenders, to other governments. Das, Papaioannou and Trebesch (2012) have published comprehensive data on sovereign debt restructurings involving the Paris Club for the years 1956-2010. These and more recent data are also available directly from the Paris Club’s website and generally show the year and the amounts of each restructuring of Paris Club debt. In some cases, the Paris Club separately identifies amounts of restructured loans and interest arrears. However, the data do not include the annual amounts of unpaid loans and accrued interest for the entire default period, although there are some cases (e.g., Sudan) where the IMF periodically publishes estimates of Paris Club loan arrears.

Despite these limitations, we publish data on Paris Club debt restructurings separately from the data on other official creditors. Where a default has occurred but we have insufficient

\footnotetext{
${ }^{6}$ Exceptions that we also include, given their size, are short-lived arrears to the Fund by Romania, Argentina and Greece of US\$1 billion in 1986, US\$2.9 billion in 2003 and US\$2.2 billion in 2015, respectively.

${ }^{7}$ Loan arrears to the International Development Association (IDA), the World Bank Group's concessional lending arm, are not included in the IBRD totals we report but are a component of the "other official creditors" category.
} 
information about the amount of debt involved, we show asterisks rather than values for the applicable year, and we record the default in the annual global total number of defaults. For some long-running defaults not yet resolved, we show IMF estimates where available or Paris Club country data for total loans, published annually for 2008 and subsequent years, as a proxy for the actual amounts involved. Our proxy has two drawbacks: on the one hand, it may include bilateral loans to debtors that are still performing; on the other, it excludes interest arrears on non-performing loans and so underestimates total values.

Other official creditors. This category covers loan arrears by governments due to the MLIs and bilateral official creditors, including national export credit and development agencies, not shown separately. In most cases, our source for the country-by-country data is the World DataBank, which reports cumulative annual amounts of unpaid interest and principal, as well as restructured debt and write-offs of interest and principal, in the years they occurred. ${ }^{8}$ With a few exceptions (noted in the appendix), we use this data as our proxy for annual amounts of other official debt in default, on a country-by-country and aggregate basis, from 1970 onwards. For 1960-69, our data are drawn mainly from IMF Staff Reports, Bittermann (1973) and Bornschier (1986).

There are three main drawbacks with this approach. First, since the World DataBank country data are not available for 1960-69, we gather data for this period from the IMF and other sources, a process that may understate the number of governments and US dollar values involved. Second, the country totals for 1970-2017 also underestimate the annual value of official debt in default because they do not take account of the total loan amounts outstanding when payment defaults take place. Third, as highlighted by Cruces and Trebesch (2011), there may be errors in some of the country data the World DataBank reports. ${ }^{9}$ Despite these shortcomings, we believe that our efforts to uncover new sources make the 1960-69 data nearly as comprehensive as the data for 1970-2017, and that for this latter period in most instances our proxy provides a reasonable approximation of the amounts of debt in default.

To calculate annual country-by-country values for this category and to minimize doublecounting, where relevant we make the following adjustments:

\footnotetext{
${ }^{8}$ The World DataBank data on official creditors' arrears exclude arrears on IMF lending.

${ }^{9}$ Cruces and Trebesch (2011) cite instances where data on debt restructurings from this source, which come from central banks and other national sources, are not consistent with data from other credible sources.
} 
- From the official creditor totals compiled by the World DataBank, we deduct IBRD loans in arrears in each year they are reported.

- We also deduct restructured Paris Club debt from the residual official creditor values in years when the latter are larger. We make this second adjustment because the Paris Club reports its data in the year it reaches agreement with the debtor government, while the World DataBank records restructured official debt and debt write-offs in the years they occur.

Our treatment of Liberia's official arrears in 2008 illustrates how we make these adjustments. To start, for this category the World DataBank reports cumulative arrears of principal and interest arrears, plus write-offs of principal and interest during the year, as US\$1,233 million. From this total, we subtract World Bank arrears of US\$179 million reported separately, and Paris Club restructurings of principal and interest of US\$1,043 million reported separately. We record the residual, US\$11 million, in the other official creditor category of the database.

Private creditors. This category refers to foreign currency-denominated lending to governments by foreign commercial creditors, including bondholders, banks and suppliers. For 1960-69, our principle sources are IMF Staff Reports and Bittermann (1973). For the 1970-2017 period, our main source for the country-by-country data is the World DataBank, which reports cumulative annual amounts of unpaid interest and principal for this category of creditors, as well as write-offs and restructurings. This data set has the same drawbacks as the official creditor data taken from the same source and, in addition, does not always appear to differentiate public and publicly guaranteed borrowers from private sector borrowers. We utilize these data in cases where we do not have separate data on bank loans and bonds, when the reported private creditor amounts are larger than the data on bank loans and bonds, and when we have sufficient information from other sources that shows arrears by private sector borrowers in the country are a small share of the total. To minimize double-counting, we subtract the annual bank loans and bond amounts from the annual private creditor values. Where a default has occurred but we have insufficient information to estimate the amount of debt involved, we show asterisks rather than values for the applicable year, and we record the default in the annual global total number of defaults.

Foreign currency bank loans. This category refers to foreign currency-denominated bilateral and syndicated loans to governments by commercial banks. For bank loan defaults resolved through a formal restructuring process and involving interest arrears, the amounts of 
debt restructured (or subject to debt buybacks) reported by Cruces and Trebesch (2011) and others generally serve as our starting point. Utilizing available information on the original terms of the loans, which typically include a variable rate of interest (often the London Interbank Offered Rate [LIBOR]) plus a spread, we compute cumulative interest arrears for the years prior to the resolution of the default and add them to the loan amounts outstanding for each year we determine that loans were in default. In cases where a payment default did not precede a bank debt restructuring, we include the debt amount in the year(s) in which the workout process occurred. Where bank loan defaults remain unresolved, we develop our annual estimates of default amounts from information on the original loans reported by Exotix (2011) and others; we may revise these data based on updated information as and when the debt is formally restructured. When defaulted obligations are denominated in another currency, we use applicable end-of-period exchange rates to convert amounts into US dollars. Where a default has occurred but we have insufficient information to estimate the amount of debt involved, we show asterisks rather than values for the applicable year, and we record the default in the annual global total number of defaults.

Foreign currency bonds. This category refers to foreign currency-denominated bonds and other marketable securities issued by governments. Where bond interest is due but unpaid, we estimate cumulative interest arrears for the years from the start to the end of the bond default based on reported bond coupons. We add these amounts to the outstanding face value of the bond for each year of default. In cases where no payment default has occurred but old bonds are subject to an exchange proposed by the government for new bonds, which results in creditor losses, we view the face value of eligible bonds to be in default from the point when a government announces an exchange to when it is completed. We view a resumption of normal debt service on existing bonds or, more typically, the completion of a bond exchange as the point at which a bond default has been resolved. This is the case in a bond exchange even when some bondholders_-known as holdout creditors-do not tender their bonds. ${ }^{10}$ Where defaulted bonds are denominated in another currency, we use applicable end-of-period exchange rates to convert amounts into US dollars.

\footnotetext{
${ }^{10}$ Holdouts are not always the only creditors who fail to participate in bond exchanges. Some bonds may be mislaid, forgotten or locked up in estates, and such creditors can surface long after the conclusion of a bond exchange. In some instances, the government may later issue additional debt on the same terms as the bond exchange to settle these claims.
} 
Local currency debt. This category refers to debt issued by a government in its own currency. ${ }^{11}$ As already noted, local currency debt defaults are only sporadically reported as such. As a result, our estimates, which we gather from national sources and/or IMF country reports, are provisional. The majority of these defaults tend to be resolved quickly. In most cases, we identify the principal amount of the debt involved and, where relevant, estimate interest arrears based on prevailing interest rates on government debt near the time of the default. To convert amounts of estimated defaulted debt into US dollars, we use the market exchange rate-or, where exchange controls are an important consideration, the black market rate-prevailing at the start of the default. ${ }^{12}$ When central banks exchange bank notes on unfavourable terms, we generally use the amounts outstanding reported in the IMF's International Financial Statistics closest to the exchange date. Where a default has occurred but we have insufficient information to estimate the amount of debt involved, we show asterisks rather than values for the applicable year, and we record the default in the annual global total number of defaults.

Summary data. In this section of the CRAG database, we aggregate the country-by-country data for sovereign defaults in global totals. The data on the total number of sovereign issuers are the authors' estimates. We tabulate data on the number of sovereigns in default based on the total number of sovereigns reported in default in the CRAG database for each year. The global total nominal US-dollar amounts for Paris Club, other official creditor and private creditor categories in 2017 are authors' estimates. The categories for data on sovereign defaults by debtor are based on IMF definitions for advanced economies (4 sovereigns in the database) and for Heavily Indebted Poor Countries (HIPC) (39), and on the JP Morgan Emerging Market Bond Index (EMBI) Global Diversified Index definitions for emergingand frontier-market sovereigns (49). The other developing countries group (53) includes all other sovereigns in the database. Our roll-up of the country data, along with the aggregate value of Paris Club lending, as well as world public debt and world GDP sourced from the April 2018 IMF World Economic Outlook and the World DataBank (2018), provides a global perspective on the scale of annual sovereign defaults from 1960 onwards.

\footnotetext{
${ }^{11}$ For sovereigns that are members of monetary unions, we consider debt denominated in the common currency to be foreign currency for purposes of this analysis.

${ }^{12}$ In the few cases involving confiscatory currency reforms where central bank data is unavailable, we develop estimates based on the ratio of currency to GDP in countries with comparable GDP per capita. We note these cases in the appendix.
} 


\section{Assessing Data Reliability}

Using a similar approach to that followed by Cruces and Trebesch (2011), we score the relative data quality of our country-by-country estimates of debt in default. On a scale of 1 (denoting high reliability) to 4 (denoting least reliability), we determine a summary score based on the average of the subscores assigned to four variables:

a. years in which default occurred

b. types of debt in default

c. characteristics of debt restructured (e.g., interest rate, original maturity)

d. consistency of information from different sources

Of course, there must be an element of judgment in an exercise that measures data reliability in relative terms. The following example, for Jamaica, helps illustrate the process we follow. We highlight Jamaica because, under our definition, it has been in default on seven debt types-IMF, Paris Club, other official creditors, private creditors, foreign currency bank loans, foreign currency bonds and local currency debt—at various times over the 1960-2017 period.

For Jamaica, since we have a fair degree of confidence that we have identified all cases of default and the years in which they occurred, we assign a score of 3 to variable a. We are relatively confident that we have identified all the types of debt involved in each case, so we score variable b at 2 . We assign a score of 3 to variable c, which addresses our knowledge about the characteristics of the debt restructured, because we are less confident about our estimates of the value of debt restructured in the 1970s and 1980s than debt restructured more recently. We find that the information from the different sources we consulted is reasonably consistent, but since arrears owed to official creditors come from the World DataBank and are subject to revision, we assign a score of 3 to subcategory d. Finally, we average the results of the subcategories, resulting in an overall score of 3.

\section{Sovereign Defaults in Historical Perspective}

The Bank of Canada's CRAG database and its future updates are helpful to researchers analyzing the economic and financial effects of sovereign defaults from 1960 onwards. The data set is particularly useful since it facilitates comparisons of the scale of individual and multiple default events with earlier episodes. As such, it can contribute to our understanding 
of ongoing risks to global financial stability. In the commentary that follows, we highlight some of the most noteworthy trends.

From the historical record, we know that for nearly 200 years the story of sovereign defaults has centred mainly, though not exclusively, on foreign currency bonds and other marketable securities. ${ }^{13}$ Cross-border bond financing for governments emerged in the 1820 s, when newly independent states in Latin America and other regions, as well as some longer-established sovereigns, began issuing bonds denominated in foreign currency in European financial centres. Defaults soon followed on a substantial scale and persisted well into the 20th century. Defaults on local currency-denominated debt also occurred but, from the available evidence, appear to have been less frequent.

After the Second World War, owing to pervasive national controls on capital movements, cross-border bond issuance by governments fell to low levels, as did defaults, and both remained low over nearly four decades. For a relatively brief period, in the 1970s and 1980s, foreign currency-denominated loans by banks eclipsed bonds in importance. Many developing and East European countries defaulted on bank loans in the 1980s and 1990s, leading to creditor losses. The banks' subsequent exit from this business, in turn, resulted in many low- and middle-income sovereigns regaining access to cross-border bond markets in the 1990s, which continues to this day.

The period since the 1990s is also noteworthy because of growing cross-border investments in the local currency-denominated market debt of emerging-market sovereigns. ${ }^{14}$ This development helped trigger a number of defaults involving such sovereigns as Russia and Argentina, where restructurings of their foreign currency bonds were also involved. These latter defaults, though also increasing, nonetheless remain well below their pre-Second World War historical peaks.

Chart 1 provides a snapshot of trends in defaults on foreign currency bonds and bank loans from 1820 to $2017 .{ }^{15}$ Because of limited historical bond data for much of this period, we calculate unweighted default rates, i.e., governments in default as a per cent of all

\footnotetext{
13 This section of the report draws in part on previous work published by Cruces and Trebesch (2011), Rieffel (2003), Reinhart and Rogoff (2009) and Suter (1992).

${ }^{14}$ For further discussion on the frequency of sovereign defaults on local currency debt, see section 7 of this report.

${ }^{15}$ The data in Chart 1 are partly based on data previously published by Beers and Chambers (2006).
} 
governments. ${ }^{16}$ For bonds, three peak default periods stand out—between the 1830 s and 1850s, when default rates exceeded 25 per cent; in the 1870s, when default rates averaged 18 per cent; and in the 1930s, when they reached 21 per cent. Of note, too, is the sharp decline in bond defaults after the Second World War that persisted through the 1980s. The resolution of many pre-war bond defaults was the main driver of the fall in the default rate. At the same time, the fragmentation of the early post-Second World War cross-border financial markets limited bond market access to only the most creditworthy borrowers, and so defaults on new issues were low.

\section{Chart 1: $\quad$ Sovereign default rates}

Foreign currency bonds and bank loans

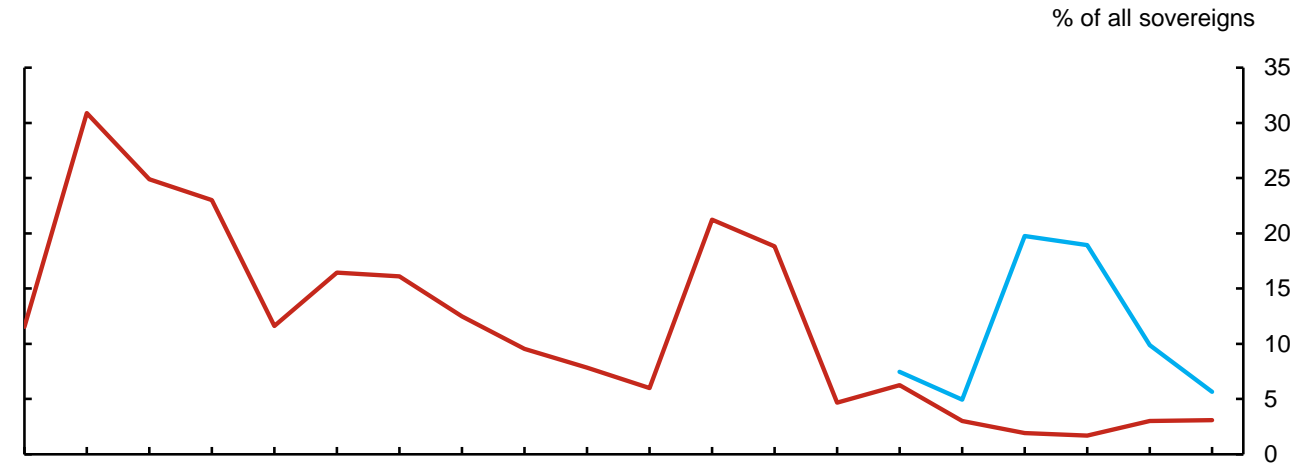

18201830184018501860187018801890190019101920193019401950196019701980199020002010

Foreign currency bonds

Foreign currency bonds and bank loans

Default rates are 10-year averages of annual data and 7-year average for 2010

Suter (1992) and CRAG database

Prior to the Second World War, sovereign defaults on official loans played only an intermittent role. Then, after 1945, lending to governments by the IMF and other newly established MLIs quickly gained prominence. These institutions, together with national export credit and development agencies, were launched in part to fill perceived gaps in public finance left by the shrinkage in the cross-border bond markets. They increasingly targeted loans to developing country governments on concessional terms, and initially defaults on official loans were low.

By the 1980s, however, the sharp rise in sovereign defaults on foreign currency bank loans shown in Chart 1 was accompanied by growing defaults on loans from official creditors.

\footnotetext{
${ }^{16}$ By our count, the total number of sovereigns globally was 36 in 1820, 65 in 1900, 105 in 1950 and 214 in 2017. Reinhart and Rogoff (2009) have calculated historical sovereign default rates weighted by estimated aggregated GDP. However, due to reliability issues relating to pre-Second World War national income data in many countries, we have not replicated this approach here.
} 
Even arrears on IMF loans surfaced, although their size was minor compared with other creditors. The factors driving both bank loans and official loans into default were often closely linked, owing to the adverse fiscal impact in many countries from the spike in world oil prices and in US short-term interest rates. The latter directly influenced the cost of syndicated bank loans contracted by many sovereign borrowers and helped ratchet up the real burden of their public debt. As seen in Chart 2, sovereign debt in default reached US $\$ 450$ billion by 1990, with debt owed to official creditors accounting for about 21 per cent of the total. By 1995, the share of official creditor debt exceeded 50 per cent.

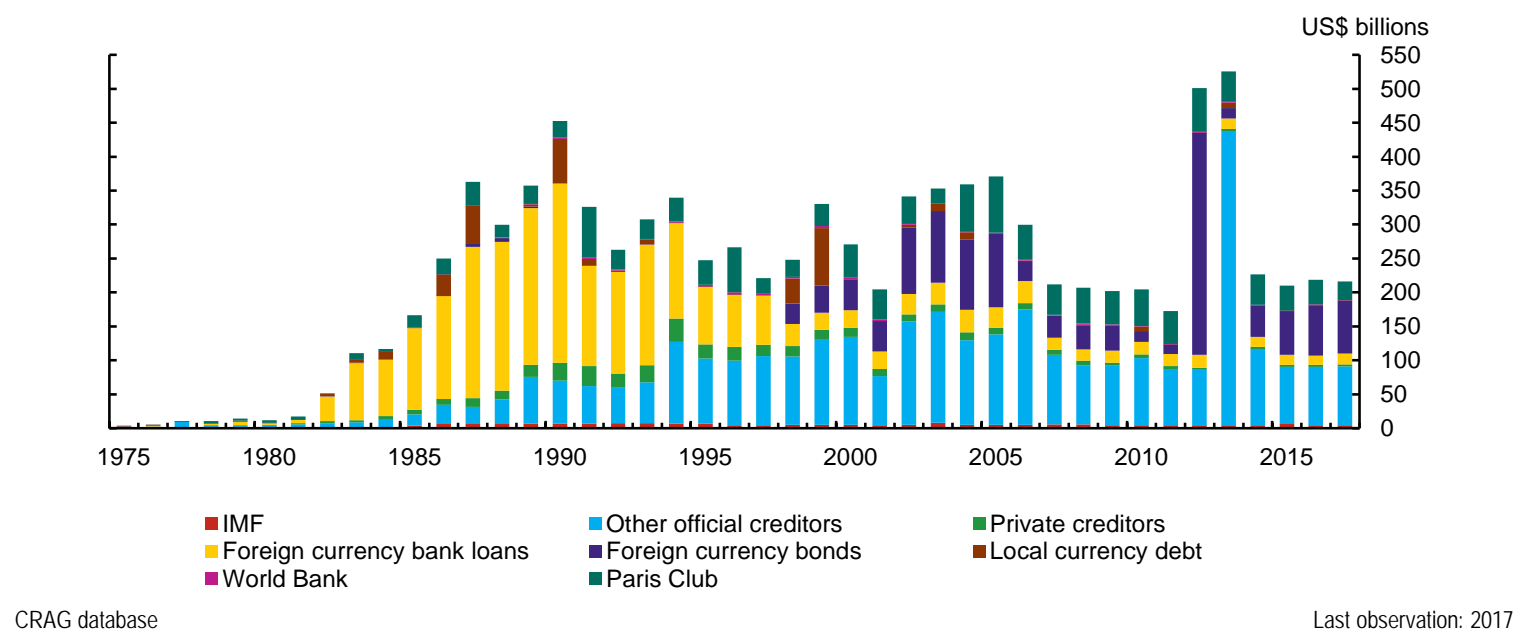

Many of the defaults on official loans continued for long periods, owing to internal economic and political difficulties of the borrowers and the reluctance of creditors to reschedule loans. However, by the 1980s, official debt restructurings led by the Paris Club became a frequent occurrence. Yet defaults on official debt persisted. This logjam eased beginning in the mid1990s, thanks to the multilateral HIPC initiative, launched with strong support from the IMF and the World Bank (IMF 2016a).

Under the program, now nearing completion, 39 low-income governments became eligible for substantial reductions in their official debt linked to implementation of agreed economic policy reforms. ${ }^{17}$ Bilateral official creditors wrote much of the debt off, while the IMF and

\footnotetext{
${ }^{17}$ Three sovereigns_-Eritrea, Somalia and Sudan—remain eligible for HIPC debt relief but have not yet commenced the process.
} 
other MLIs also agreed to participate through the MDRI. ${ }^{18}$ As a result, and as seen in Chart 2, the dollar amounts of IMF, World Bank, Paris Club and other official debt in default have mostly fallen since 2006.

That said, two recent developments are worth noting. One is the spike in problematic official debt that occurred in 2013 (Chart 2). This resulted from the restructuring (albeit without any interruption of scheduled debt service) of loans to Greece, Ireland and Portugal agreed to by their European Union partners. ${ }^{19}$ While fiscal pressures in the euro area have largely abated since then, Greece remains an exception, as highlighted by the delay in its payment of US\$2.2 billion due to the IMF in 2015 and the still-open question of whether Greece will receive additional debt relief from its official creditors. ${ }^{20}$

The second noteworthy development is that loan arrears persist in the majority of HIPC countries, amounting to about US\$11 billion in 2017 (Chart 3), partly due to the slow pace at which non-Paris Club official creditors are implementing debt relief. ${ }^{21}$ Official creditor holdouts may be less well known than litigious holdout bondholders but, like them, can also delay the resolution of defaulted debt.

\footnotetext{
${ }^{18}$ Government donors funded write-offs of IMF and MLI loans, which under the MDRI can reach 100 per cent, to avoid damaging the institutions' balance sheets and weakening their preferred creditor status.

${ }^{19}$ For Greece, creditors reduced interest rates and charges and deferred debt service, while they extended average maturities of European Union/euro area official loans to Greece, Ireland and Portugal by up to seven years. Given their terms, these official debt restructurings are consistent with our definition of sovereign defaults because they result in creditor losses in present-value terms.

20 This could still be the case, even with the 10-year extension of scheduled principal and interest payments on debt of US\$110.9 billion agreed to with euro area official creditors on 21 June 2018 (Khan and Brunsden 2018). ${ }^{21}$ Alongside persistent arrears to non-Paris Club official creditors, it is noteworthy that two HIPC sovereigns, the Republic of Congo and Mozambique, defaulted on over US\$3.5 billion of bonds and bank loans in 2016-17.
} 


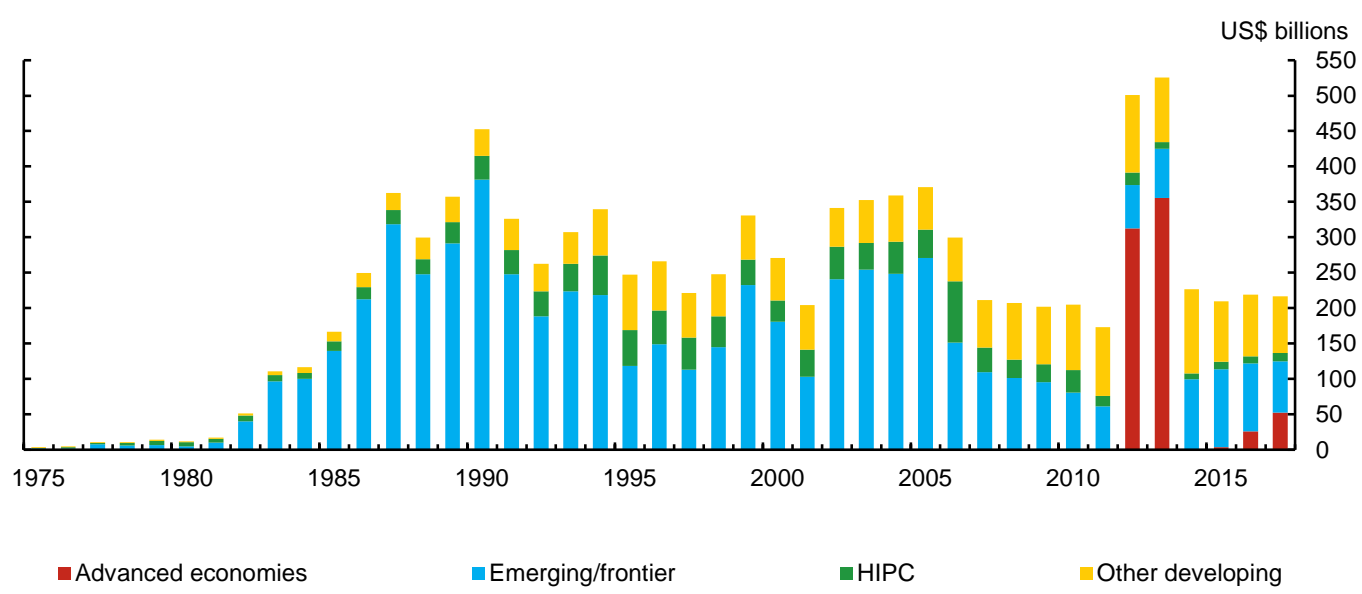

Source: CRAG database

Last observation: 2017

Chart 4 scales the nominal value of debt in default by nominal global public debt and GDP to measure the relative importance of sovereign defaults. At the start of the 1980s, defaults had minimal impact globally. However, by the middle of the decade, fiscal stresses affecting lowand middle-income countries were significant - the sovereign debt that defaulted and was restructured and in many cases ultimately written down peaked at about 6 per cent of global public debt. The increase was milder in terms of global GDP, rising from near zero to just over 2 per cent.

Chart 4 also shows that the global footprint left by these debt workouts has since faded, despite Argentina’s big default in 2001 and the more recent restructurings of sovereign bonds and official loans in the euro area. Nonetheless, the frequency of such events could be on the rise again and may be more closely correlated with rising public debt burdens than at any time since the 1930s. With many advanced and emerging-market governments grappling with fiscal challenges, these are trends worth watching alongside other potential risks to global financial stability. 
Chart 4: Sovereign debt in default as a share of world public debt and world GDP

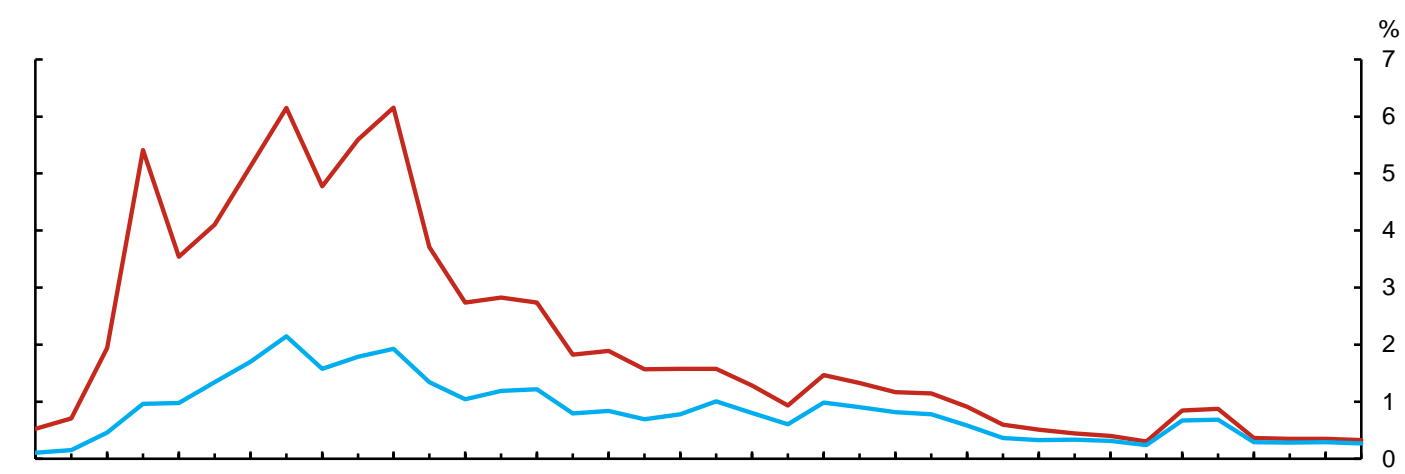

1980198219841986198819901992199419961998200020022004200620082010201220142016

\section{Special Topic: How Frequently Do Sovereigns Default on Local Currency Debt?}

Chart 5: Private creditor local currency vs. foreign currency debt defaults

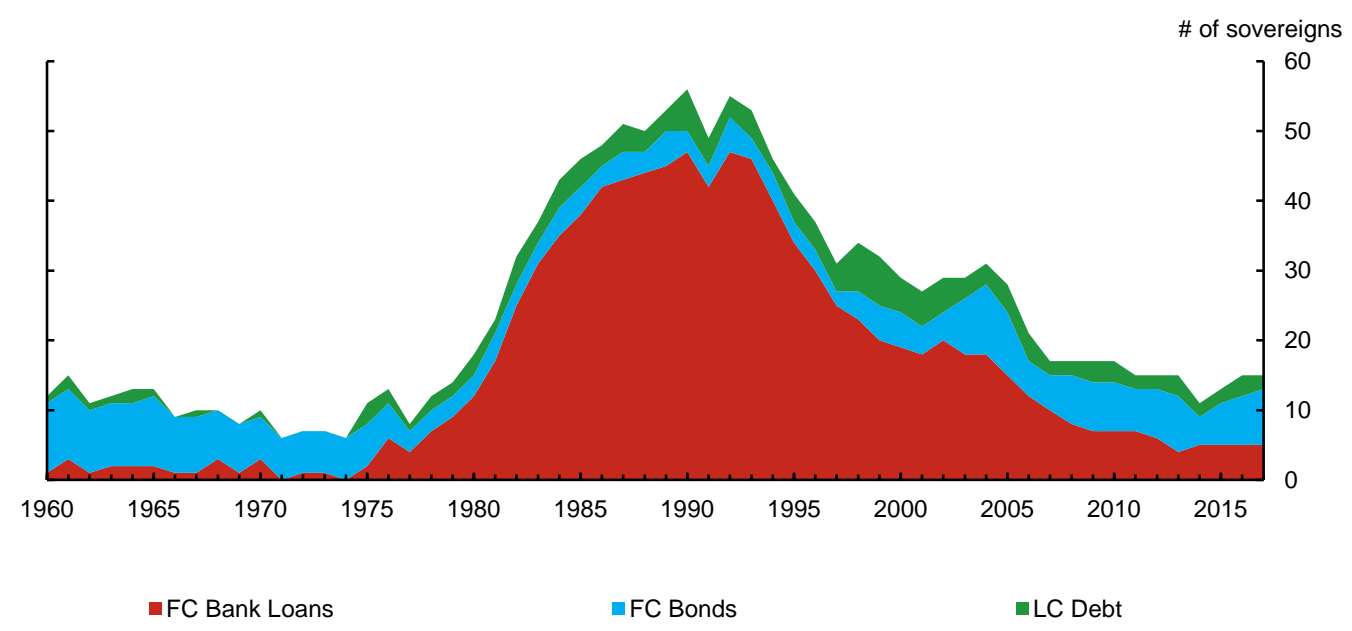

Source: CRAG database

Last observation: 2017

A long-held view among some market participants is that governments rarely default on local currency sovereign debt. ${ }^{22}$ After all, they argue, governments can service such obligations by

\footnotetext{
${ }^{22}$ This section of the report draws in part on previous work published by Beers and Chambers (2006) and, on confiscatory currency exchanges, by Mas (1995).
} 
printing money, which in turn can reduce the real burden of debt through inflation, dramatically so in cases like Hungary in 1945-46 and Zimbabwe in 2007-08.

Of course, high inflation can be a form of de facto default on local currency debt. Still, outside these exceptional episodes, contractual defaults and restructurings of local currency debt do occur and are more common than is often supposed. A key objective of our work updating the sovereign default database in this report is to document such cases.

Identifying local currency defaults is challenging in part because governments rarely acknowledge them. Another factor contributing to the limited visibility of these defaults is that impacted investors are mostly domestic residents with limited avenues of redress. Crossborder investment in sovereign local currency debt instruments, a phenomenon dating back to the 1990s, has undoubtedly contributed to greater awareness of more recent default cases.

Thus far, we have identified 31 sovereigns involved in local currency defaults between 1960 and 2017. These defaults take different forms. Perhaps most surprising is the number involving the exchange of old currency for new on confiscatory terms. We found that 16 sovereigns have undertaken such exchanges, with some (e.g., Ghana, North Korea, Myanmar and USSR/Russia) doing so more than once. Losses result because of the conditionality authorities typically impose-notably setting short time frames in which exchanges of old bank notes for new can occur, placing limits on amounts that can be exchanged, requiring that notes above such limits be deposited in blocked accounts, and barring participation by foreign holders of old currency in such exchanges.

The factors triggering confiscatory currency reforms appear to be idiosyncratic — they can follow a change in political regimes or be part of an official strategy to curtail black markets. As such, these defaults do not always reflect broader financial distress. Among the countries involved, there are only three cases (Nicaragua, USSR/Russia and Venezuela) where the government also defaulted on other types of local currency debt, although many more ultimately defaulted on their foreign currency debt. Other cases of default on local currency debt involve overdue interest and principal payments and/or restructurings of maturities (15), unilateral reductions in real interest rate coupons on inflation-linked debt (2), restructuring and conversion into foreign currency debt (1), and new taxes targeting local currency debt service (1). 
Chart 5 tracks the annual number of defaults on local currency debt we have identified in the 1960-2017 period compared with defaults on foreign currency bank loans and bonds, the two other principal types of sovereign debt owed to private creditors. Through nearly half the survey period, defaults on foreign currency bank loans predominated. However, since the mid-1990s, as international banks curtailed their sovereign lending, defaults on foreign currency bonds have increased. The frequency of defaults on local currency debt has been more variable: their number gradually picked up after the 1970s but has trended down again since the early 2000s. Over the past decade, between four and eight sovereigns have defaulted on foreign currency bonds each year and between two and three on local currency debt.

Interestingly, since 1960, defaults on foreign and local currency market debt by the same sovereign have happened concurrently less than half the time. These patterns may be starting to shift, however, as government debt burdens grow alongside domestic debt markets, attracting higher cross-border investment. As a result, defaults on local currency debt could become as common as defaults on foreign currency bonds in future episodes of sovereign debt distress. ${ }^{23}$

\section{Conclusion}

The Bank of Canada's CRAG database is useful to researchers analyzing the economic and financial effects of individual sovereign defaults and, importantly, the impact on global financial stability of episodes involving multiple sovereign defaults. Our database draws on previously published data sets compiled by various official and private sector sources. It combines elements of these, together with new information, to develop estimates of stocks of government obligations in default, including bonds and other marketable securities, bank loans and official loans in default, valued in US dollars, from 1960 onwards on both a country-by-country and a global basis. The database applies a common standard for determining when defaults occur. However, documenting which sovereigns have defaulted, the time frame of such defaults and the amounts of debt affected can be challenging. While we have relied on sources we consider reliable, our database of sovereign defaults may not be

\footnotetext{
${ }^{23}$ Our efforts to identify local currency defaults currently focus on securitized debt. In other words, we exclude some types of domestic fiscal arrears - such as overdue payments to suppliers, civil servants, and pensionerseven though, when lawfully contracted, these too are government obligations. With that in mind, where such arrears can be quantified, we may include them in future updates of the sovereign default database.
} 
exhaustive. Additional information on defaults, as it becomes available, will be incorporated in future database updates.

\section{References}

Alpert, L. I. 2012. “Russia, North Korea Sign Debt Pact.” Wall Street Journal, 18 September.

Argentina, Republic of. 2016. “Preliminary Offering Memorandum.” 11 April.

Asian Development Bank (AsDB). 2001-2008. Annual Reports. 2018. Statistical Database System (SDBS). Available at https://sdbs.adb.org/sdbs/index.jsp.

Asonuma, A., M. X. Li and M. G. Papaioannou. 2017. "Sovereign Debt Restructurings in Grenada: Causes, Processes, Outcomes, and Lessons Learned.” IMF Working Paper No. $\mathrm{WP} / 17 / 171$.

Banco Central de Venezuela. 2017. Available at http://www.bcv.org.ve/.

Beers, D. and J. Chambers. 2006. "Sovereign Defaults at 26-Year Low, to Show Little Change in 2007.” S\&P Global. Available at http://www.standardandpoors.com/en_US/web/guest/article/-/view/sourceId/3859722.

Bittermann, H. J. 1973. The Refunding of International Debt. Durham: Duke University Press.

Bloomberg. 2016. Grenada Government Bond Data. Accessed 1 March 2016.

Bornschier, V., U. Pfister and C. Suter. 1986. Unpublished data on restructurings of sovereign debt owed official and private creditors provided to the authors by Dr. Suter.

Boughton, J. M. 2001. Silent Revolution: The International Monetary Fund 1979-1989. The International Monetary Fund. Available at https://www.imf.org/external/pubs/ft/history/2001/.

Central Bank of Sri Lanka (CBSL). 1996. “Weekly Treasury Bill Auctions.” Available at http://www.cbsl.gov.lk/.

Chari, A., R. Leary and T. Phan. 2018. "The Costs of (sub)Sovereign Default Risk: Evidence from Puerto Rico.” Working Paper No. 18-03, Federal Reserve Bank of Richmond.

Council of the Corporation of Foreign Bondholders (CCFB). Various years. Annual Report. Available at https://searchworks.stanford.edu/view/357970.

Cruces, J. and C. Trebesch. 2011. "Sovereign Defaults: The Price of Haircuts.” Working Paper No. 3604, Münchener Gesellschaft zur Förderung der Wirtschaftswissenschaft - 
CESifo GmbH. Bond and bank loan restructuring data available at https://sites.google.com/site/christophtrebesch/data.

Culverhouse, S. 2018. “Waiting for the Elections.” Exotix Capital. 11 April.

Das, U. S., M. G. Papaioannou and C. Trebesch. 2012. "Sovereign Debt Restructurings 19502010: Literature Survey, Data, and Stylized Facts.” IMF Working Paper No. WP/12/203. Paris Club debt restructuring data available at https://sites.google.com/site/christophtrebesch/data.

Diwan, I. and F. Saldanha. 1991. "Long Term Prospects in Eastern Europe: The Role of External Finance in an Era of Change.” World Bank. 30 June.

Duggar, E. and M. Leos. 2015. “FAQ on Peru Bonos de la Deuda Agraria.” Moody’s Investors Service. 18 December.

Durant, I. 2012. "Recent Restructurings of Sovereign Commercial Debt in the Caricom Region: Some Outcomes and Lessons.” Caribbean Development Bank. Available at http://www.caribank.org/uploads/2014/02/Debt_Restructuring_Caribbean_Ian-Durant.pdf.

European Commission. 2013a. "Statement by the European Commission and the IMF on Cyprus.” Available at http://europa.eu/rapid/press-release_MEMO-13-624_en.htm.

. 2013b. “Economic Adjustment Programme for Ireland.” Available at http://ec.europa.eu/economy_finance/assistance_eu_ms/ireland/index_en.htm.

. 2013c. "Programme for Portugal.” Available at http://ec.europa.eu/economy_finance/assistance_eu_ms/portugal/index_en.htm.

European Union. 2013. "Statement by the Eurogroup and ECOFIN Ministers on Ireland and Portugal.” Available at http://eu2013.ie/news/newsitems/20130412eurogroupecofinpressstatement/.

Exotix Capital. 2011. Exotix Frontier Markets Guidebook.

Ferguson, N. and B. Granville. 2000. "Weimar on the Volga: Causes and Consequences of Inflation in 1990s Russia Compared with 1920s Germany.” The Journal of Economic History 60 (4): 1061-87.

Ferris, J. 2011. "Guns for Cotton? Aid, Trade, and the Soviet Quest for Base Rights in Egypt, 1964-1966.” The Journal of Cold War Studies 13 (2): 4-38.

Firebird Global Master Fund II Ltd. v. Republic of Nauru, U.S. District Court. 2012. District of Columbia, Case 1:12-cv-00230. Available at https://www.docketalarm.com/cases/District_Of_Columbia_District_Court/1--12-cv00230/FIREBIRD_GLOBAL_MASTER_FUND_II_LTD._V._REPUBLIC_OF_NAURU/

Flynn S. and M. Pessoa. 2014. "Prevention and Management of Government Expenditure Arrears.” May. Available at https://www.imf.org/external/pubs/ft/tnm/2014/tnm1403.pdf. 
Foreign Bondholders Protective Council, Inc. (FBPC). Various years. Annual Report. Available at https://searchworks.stanford.edu/view/357970.

Foy, H., J. P. Rathbone and K. Allen. 2017. "Russia and Venezuela Agree \$3 Billion Debt Restructuring.” Financial Times. 15 November. Available at https://www.ft.com/content/5f3084c6-ca03-11e7-ab18-7a9fb7d6163e.

Francis, R. 2017. “Fitch Upgrades El Salvador's Long-Term Issuer Default Rating to 'CCC' from 'RD'.” Fitch Ratings. 3 May.

Ghabra, S. 1991. “The Iraqi Occupation of Kuwait: An Eyewitness Account.” Journal of Palestine Studies 20 (2): 112-25.

Government of Puerto Rico. 2017. “Fiscal Plan for Puerto Rico.” 13 March. Available at http://www.gdb-pur.com/investors_resources/presentations.html

Grigorian, D., T. Alleyne and A. Guerson. 2012. “Jamaica Debt Exchange.” International Monetary Fund Working Paper No. WP/12/244.

Haggard, S. and M. Noland. 2010. "The Winter of Their Discontent: Pyongyang Attacks the Market.” Peterson Institute of International Economics Policy Brief No. PB10-1.

Haver Analytics. 2017. Available at http://www.haver.com/.

Hitchcock, D. G., G. J. Petek and H. G. Aldrete-Sanchez. 2015. "Rating on Three Puerto Rico PFC Series Lowered To 'D' On Non-Payment.” S \& P Global. Available at http://www.gdb-pur.com/investors_resources/documents/SP-RatingsDirectNews-Aug-032015.pdf.

Hwang. E-G. 2010. "Signs of Big Bang in North Korea.” International Centre for the Study of East Asian Development. May. Available at www.agi.or.jp/workingpapers/WP2010$\underline{11 . p d f}$

International Monetary Fund (IMF). Various years. Annual Reports. . Various years. Article IV and Lending Program Staff Reports.

_ Various years. International Financial Statistics (IFS) via Haver Analytics.

_. 2001. “Sri Lanka: Recent Economic Developments. 21 March. . 2004. "Dominica: Second Review Under the Three-Year Arrangement Under the Poverty Reduction and Growth Facility.” 22 July. . 2005. "Republic of Madagascar: Selected Issues and Statistical Appendix.” September. . 2007. "Public Debt Markets in Central America.” June. 
2013a. Historical Public Debt Database (March). Available at http://www.imf.org/external/ns/cs.aspx?id=262.

2013b. "Greece: First and Second Reviews Under the Under the Extended Arrangement Under the Extended Fund Facility, Request for Waiver of Applicability, Modification of Performance Criteria, and Rephasing of Access.”

. 2013c. "Statement by the European Commission and the IMF on Cyprus."

. 2013d. "Sovereign Debt Restructuring-Recent Developments and Implications for the Fund’s Legal and Policy Framework.” 26 April.

. 2013e. "St. Kitts and Nevis_Fourth Review Under the Stand-By Arrangement.” 21 February.

. 2015a. "Statement by the IMF on Greece." 20 July. Available at http://www.imf.org/external/np/sec/pr/2015/pr15344.htm.

. 2015b. "IMF Executive Board Takes Decision on the Status of Ukraine's Eurobond Held by the Russian Federation.” 16 December. Available at https://www.imf.org/external/np/sec/pr/2015/pr15570.htm.

. 2016a. "Heavily Indebted Poor Countries (HIPC) Initiative and Multilateral Debt Relief Initiative (MDRI) - Statistical Update.” March. Available at https://www.imf.org/external/pp/longres.aspx?id=5024.

. 2016b. "Liberia: Fourth Review Under the Extended Credit Facility Arrangement." January. Available at http://www.imf.org/external/pubs/cat/longres.aspx?sk=43587.0. 2016c. “Tanzania: Third Review Under the Policy Support Instrument.” February. Available at http://www.imf.org/external/pubs/ft/scr/2016/cr1629.pdf.

. 2018. World Economic Outlook Database (April). Available at http://www.imf.org/external/pubs/ft/weo/20173/01/weodata/index.aspx.

J.P. Morgan. 2018. “Index Packages.” Available at https://www.jpmorgan.com/country/US/EN/jpmorgan/investbk/research/indexresearch/ve ndor/packages.

Kaske, M. and S. Sivaloganathan. 2016. "Puerto Rico Faces Record Default: A Look at the Bonds Due.” Bloomberg. 30 June.

Khan, M. and J. Brunsden. 2018. “Eurozone Creditors Reach 'Historic' Deal on Greek Debt Relief.” Financial Times. 21 June.

King, M. 2004. “The Institutions of Monetary Policy - The Ely Lecture 2004.” Bank of England. Available at http://www.bankofengland.co.uk/archive/Documents/historicpubs/speeches/2004/speech2 08.pdf. 
Krassowski, A. 2014. Development and the Debt Trap: The Case of Ghana. Routledge.

Kroll Associates U.K. Ltd. 2017. "Independent Audit Related to Loans Contracted by ProIndicus S. A., EMATUM S.A. and Mozambique Asset Management S.A.” 23 June.

Lazard Asset Management. 2015. “Index Benchmarks for Emerging Market Debt.” Available at

http://www.lazardnet.com/us/docs/sp0/19863/EmergingMarketsDebtBenchmarks.pdf?pag ename=Literature+and+Research.

Linzmayer, O. 2016. The Banknote Book. Available at http://www.banknotenews.com/.

Makoshori, S. 2015. “Zimbabwe: Gold Debts Afflict Mines.” Financial Gazette (Harare). 11 June.

Malik, H., ed. 1990. Domestic Determinants of Soviet Foreign Policy towards South Asia and the Middle East. St. Martin's Press.

Mander, B. 2016. “Argentina Puts an End to Long Holdouts Saga.” Financial Times. 22 April.

Martin, S. 2017. "Russia Confirms Venezuelan Regime Defaulted on Billion Dollar Debt.” PanAm Post. 8 June. Available at https://panampost.com/sabrinamartin/2017/06/08/russia-venezuelan-regime-billion-dollar-debt/.

Mas, I. 1995. “Things Governments Do to Money: A Recent History of Currency Reform Schemes and Scams.” Kyklos 48: 463-512.

Mellor, W. 2014. “GE Poised to Bankrupt Nauru, Island Stained by Money-Laundering.” Bloomberg. 1 June.

Olearchyk, R. 2015. “Ukraine’s Parliament Approves Debt Restructuring Deal.” Financial Times. 17 September.

Pacific Islands Report. 2003. “Saipan Bank Sues Nauru for Unpaid Loan.” East-West Centre. 25 April.

Paris Club. 2018. “Paris Club Agreements.” Available at http://www.clubdeparis.org/.

Paulson, J. 1999. African Economies in Transition: Volume 2: The Reform Experience. Macmillan.

Prasso, S. 2001. “The Riel Value of Money: How the World's Only Attempt to Abolish Money has Hindered Cambodia’s Economic Development.” East-West Centre, January.

Raynaud, M. 2017. “Republic of Congo Foreign Currency Rating Lowered to ‘SD/D’ After Trustee Unable to Unfreeze Bond Payments.” S\&P Global, 1 August. 
Reinhart, C. and K. Rogoff. 2009. This Time Is Different: Eight Centuries of Financial Folly. Princeton University Press.

Rieffel, L. 1985. The Role of the Paris Club in Managing Debt Problems. Princeton University Essays in International Finance.

_. 2003. Restructuring Sovereign Debt: The Case for Ad Hoc Machinery. Brookings Institution Press.

Schipani, A. and R. Wigglesworth. 2015. "Hedge Fund Threatens Peru Over Debts to Former Landowners.” Financial Times. 9 October.

Schipke, A., A. Cebotari and N. Thacker, (eds. 2013. The Eastern Caribbean Economic and Currency Union: Macroeconomics and Financial Systems. International Monetary Fund.

Shpakovsky, V. 2013. "Financial Reforms in 1991 Drove USSR into the Grave.” Pravda. 16 July. Available at http://www.pravdareport.com/business/finance/16-07-2013/125160financial_reforms_soviet_union-0/\#sthash.olNWYjtj.dpuf.

Stanič, A. 2001. "Financial Aspects of State Succession: The Case of Yugoslavia.” European Journal of International Law 12 (4): 751-79.

Sturzenegger, F. and J. Zettelmeyer. 2005. "Haircuts: Estimating Investor Losses in Sovereign Debt Restructurings, 1998-2005.” International Monetary Fund Working Paper No. WP/05/137.

Suter, C. 1992. Debt Cycles in the World-Economy: Foreign Loans, Financial Crises, and Debt Settlements, 1820-1990. Westview Press.

Tomz, M. and L. J. Wright. 2012. "Empirical Research on Sovereign Debt and Default.” Federal Reserve Bank of Chicago Working Paper No. 2012-06.

Tudela, M., E. Duggar, A. Metz and B. Oosterveld. 2011. "Sovereign Default and Recovery Rates, 1983-2010.” Moody’s Investors Service. 10 May.

Tweedie, A., S. Hagan and S. Tiwari. 2012. "Review of the Fund's Strategy on Overdue Financial Obligations.” International Monetary Fund.

Ukraine. 2014. “Prospectus.” 17 February.

U.S. Securities and Exchange Commission (SEC), EDGAR System. Various years. Annual Report for Foreign Governments and Political Subdivisions (Republic of Argentina). Available at http://www.sec.gov/cgi-bin/browseedgar?action=getcompany \&CIK=0000914021 \&type $=\&$ dateb $=\&$ owner $=$ exclude $\&$ start $=0$ \&count $=40$.

Unsigned. 1987. “Egypt in Accord on Soviet Debt.” New York Times. 2 April. 
Unsigned. 2002. "Swift collapse. The Economist. 30 May. Available at http://www.economist.com/node/1158491.

Wallace, P. 2016. “Republic of Congo’s Bonds Rally as Overdue Debt Payment Made.” Bloomberg. 9 August. Available at https://www.bloomberg.com/news/articles/2016-0809/republic-of-congo-s-bonds-rally-as-overdue-debt-payment-made

Walters, R. 1970. American and Soviet Aid: A Comparative Analysis. University of Pittsburgh Press.

World Bank. 1980-2017. Annual IBRD Financial Statements.

_ Various years. World Development Report. . 2012. "Debt Reduction Facility for IDA-Only Countries: Progress Update and Request for Extension."

2013. "International Bank for Reconstruction and Development Places Loans to Islamic Republic of Iran in Non-Performing Status.” 18 July. Available at http://www.worldbank.org/en/news/press-release/2013/07/18/international-bankreconstruction-development-places-loans-islamic-republic-iran-non-performing-status.

2018. World DataBank. Available at http://data.worldbank.org/topic/economicpolicy-and-external-debt.

Yun, Joseph. 2010. “Cambodia’s Small Debt: When Will the U.S. Forgive?” U.S. Department of State. 30 September. Available at https://www.gpo.gov/fdsys/pkg/CHRG111hhrg61519/html/CHRG-111hhrg61519.htm

Zettelmeyer, J., C. Trebesch and M. Gulati. 2013. “The Greek Debt Restructuring: An Autopsy.” Working Paper No. 4333, Münchener Gesellschaft zur Förderung der Wirtschaftswissenschaft - CESifo GmbH.

Zimbabwe, Republic of. 2015. Reserve Bank of Zimbabwe (Debt Assumption) Act, 2015. Available at http://www.zimlii.org/zw/legislation/numact/2015/2/2015/Reserve\%20Bank\%20of\%20Zimbabwe\%20\%28Debt\%20Assumption\%2 9\%20Act, \%202015.pdf. 


\section{Appendix}

Below are the sources we use to compile the CRAG database.

\section{Global Aggregates}

IFS via Haver, IMF (2013a, 2018), J.P. Morgan (2018), Lazard (2015), Paris Club (2018), World Bank (1980-2017), World DataBank via Haver.

\section{Afghanistan}

Das, Papaioannou and Trebesch (2012), IMF Annual Reports (1997-2002), IMF Article IV Staff Reports (1965-67, 1976, 1981-87, 2005-12), IMF (2016a), Paris Club (2018), World Bank Financial Statement (2000), World DataBank via Haver. Note: World DataBank data on debt owed to other official creditors are not available prior to 1993 and for private creditors prior to 1992. Data on other official creditors in earlier years are based on IMF Staff Reports.

\section{Albania}

Das, Papaioannou and Trebesch (2012), Exotix (2011), Flynn and Pessoa (2014), Paris Club (2018), World Bank (2012), World DataBank via Haver.

\section{Algeria}

Cruces and Trebesch (2011), Das, Papaioannou and Trebesch (2012), Exotix (2011), Paris Club (2018), World DataBank via Haver.

\section{Angola}

Beers and Chambers (2006), Das, Papaioannou and Trebesch (2012), Exotix (2011), Flynn and Pessoa (2014), IFS via Haver, IMF (2016a), IMF Article IV Staff Report (1993). Linzmayer (2016), Paris Club (2018), Paulson (1999), World DataBank via Haver. Note: Angola's 1990 local currency default was the result of a confiscatory currency reform.

\section{Antigua and Barbuda}

Das, Papaioannou and Trebesch (2012), Durant (2012), IMF (2013e), IMF Article IV Staff Reports (2004-14), Paris Club (2018), Schipke, Cebotari and Thacker (2013).

\section{Argentina}

Argentina (2016), authors' conversation with the IMF staff, Beers and Chambers (2006), Cruces and Trebesch (2011), Das, Papaioannou and Trebesch (2012), Durant (2012), IMF Article IV Staff Reports (1961-66), Mander (2016), Paris Club (2018), Sturzenegger and Zettelmeyer (2005), Suter (1986), U.S. SEC Financial Statements (2003, 2006, 2011, 2018), World DataBank via Haver, World Development Report (1983).

\section{Armenia}

World DataBank via Haver.

\section{Azerbaijan}

World DataBank via Haver.

\section{Bangladesh}

World DataBank via Haver. 


\section{Belarus}

World DataBank via Haver.

\section{Belize}

Beers and Chambers (2006), Cruces and Trebesch (2011), Durant (2012), Exotix (2011), IMF Article IV Staff Report (2014), Schipke, Cebotari and Thacker (2013), World DataBank via Haver.

\section{Benin}

Das, Papaioannou and Trebesch (2012), IMF (2016a), IMF Article IV Staff Reports (196170), Paris Club (2018), World DataBank via Haver.

\section{Bhutan}

World DataBank via Haver.

\section{Bolivia}

Beers and Chambers (2006), Bittermann (1973), Cruces and Trebesch (2011), Das, Papaioannou and Trebesch 2012), FBPC (1970), IMF (2016a), IMF Article IV Staff Reports (1961-67), Paris Club (2018), World Bank (2012), World DataBank via Haver.

\section{Bosnia \& Herzegovina}

Cruces and Trebesch (2011), Das, Papaioannou and Trebesch (2012), Exotix (2011), Flynn and Pessoa (2014), IMF Annual Reports (1993-95), Paris Club (2018), Stanič (2001), World DataBank via Haver.

\section{Botswana}

World DataBank via Haver.

\section{Brazil}

Beers and Chambers (2006), Bittermann (1973), Cruces and Trebesch (2011), Das, Papaioannou and Trebesch (2012), IMF Article IV Staff Reports (1961-66), Paris Club (2018), Rieffel (1985), World DataBank via Haver.

\section{Bulgaria}

Cruces and Trebesch (2011), CCFB (1987), Das, Papaioannou and Trebesch (2012), FBPC (1987), Paris Club (2018), World DataBank via Haver.

\section{Burkina Faso}

Das, Papaioannou and Trebesch (2012), IMF (2016a), Paris Club (2018), World DataBank via Haver.

\section{Burundi}

Das, Papaioannou and Trebesch (2012), IMF (2016a), Paris Club (2018), Beers and Chambers (2006), World DataBank via Haver.

\section{Cabo Verde}

Beers and Chambers (2006), Cruces and Trebesch (2011), IMF Article IV Staff Report (2003), World DataBank via Haver. Note: Local currency debt in default in 1999-2001 reflects interest arrears and the conversion of some instruments into longer-term low-interest foreign currency debt financed by external donors. 


\section{Cambodia}

Boughton (2001), Das, Papaioannou and Trebesch (2012), IMF Annual Reports (1978-93), IMF Article IV Staff Reports (1972-91), IMF (2013a), Paris Club (2018), Prasso (2001), Suter (1986), World Bank (2012), World DataBank via Haver, Yun (2010). Note: The 1975 local currency default was the result of the Pol Pot regime's abolition of money. As central bank records are not available, currency data for Laos, with comparable per capita US-dollar GDP in 1975, was used to calculate a proxy value for Cambodian defaulted currency.

\section{Cameroon}

Beers and Chambers (2006), Cruces and Trebesch (2011), Das, Papaioannou and Trebesch (2012), IMF (2016a), Paris Club (2018), World Bank (2012), World DataBank via Haver.

\section{Central African Republic}

Das, Papaioannou and Trebesch (2012), Flynn and Pessoa (2014), IMF (2016a), Paris Club (2018), Rieffel (1985), World DataBank via Haver.

\section{Chad}

Boughton (2001), IMF Annual Report (1984), IMF Extended Credit Facility Arrangement Staff Report (2016), IMF (2016a), Paris Club (2018), World DataBank via Haver.

\section{Chile}

Beers and Chambers (2006), Bittermann (1973), Cruces and Trebesch (2011), Das, Papaioannou and Trebesch (2012), IMF Article IV Staff Reports (1961, 1963-67, 1971-76), Paris Club (2018), World DataBank via Haver.

\section{Colombia}

World DataBank via Haver.

\section{Comoros}

Das, Papaioannou and Trebesch (2012), IMF (2016a), Paris Club (2018), World Bank Financial Statement (2000), World DataBank via Haver.

\section{Rep. of Congo (Brazzaville)}

Cruces and Trebesch (2011), Das, Papaioannou and Trebesch (2012), Exotix (2011), IMF (2016a), Paris Club (2018), Raynaud (2017), Wallace (2016), World Bank Financial Statements (2000-01), World DataBank via Haver.

\section{Dem. Rep. of Congo (Kinshasa)}

Boughton (2001), Cruces and Trebesch (2011), Das, Papaioannou and Trebesch (2012), FBPC (1965), IMF Annual Reports (1988-89, 1992-2002), IMF (2016a), Paris Club (2018), Rieffel (1985), World Bank Financial Statements (2000-02), World DataBank via Haver, World Development Report (1983).

\section{Cook Islands}

AsDB SDBS (2018), Beers and Chambers (2006).

\section{Costa Rica}

Cruces and Trebesch (2011), Das, Papaioannou and Trebesch (2012), IMF Article IV Staff Report (1962-66), Paris Club (2018), Rieffel (1985), World DataBank via Haver. 


\section{Côte d'Ivoire}

Cruces and Trebesch (2011), Das, Papaioannou and Trebesch (2012), Exotix (2011), Flynn and Pessoa (2014), IMF (2016a), Paris Club (2018), World Bank (2012), World Bank Financial Statements (2001, 2005-08), World DataBank via Haver.

\section{Croatia}

Beers and Chambers (2006), Cruces and Trebesch (2011), Das, Papaioannou and Trebesch (2012), Paris Club (2018).

\section{Cuba}

Cruces and Trebesch (2011), Das, Papaioannou and Trebesch (2012), Exotix (2011), FBPC (1962), IMF Article IV Staff Report (1961), IFS via Haver, Paris Club (2018), Rieffel (1985). Note: Cuba's 1961 local currency default was the result of a confiscatory currency reform. We have revised values for defaulted Paris Club debt in 1986-2014 to reflect interest arrears restructured in the 2015 agreement. We have also revised the value of bank loans in default between 1985 and 2017 to reflect additional information on their terms.

\section{Cyprus}

European Commission (2013a), IMF (2013c).

\section{Czechoslovakia}

CCFB (1986), FBPC (1986).

\section{Djibouti}

Das, Papaioannou and Trebesch (2012), Paris Club (2018), World DataBank via Haver.

\section{Dominica}

Cruces and Trebesch (2011), Durant (2012), IMF (2004), IMF Article IV Staff Report (2013), Schipke, Cebotari and Thacker (2013), World DataBank via Haver.

\section{Dominican Republic}

Beers and Chambers (2006), Bittermann (1973), Cruces and Trebesch (2011), Das, Papaioannou and Trebesch (2012), Paris Club (2018), Exotix (2011), IMF Article IV Staff Reports (1961-70), Schipke, Cebotari and Thacker (2013), World DataBank via Haver.

\section{Ecuador}

Cruces and Trebesch (2011), Das, Papaioannou and Trebesch (2012), Paris Club (2018), Sturzenegger and Zettelmeyer (2005), World DataBank via Haver.

\section{Egypt}

Bornschier, Pfister and Suter (1986), Das, Papaioannou and Trebesch (2012), IMF Article IV Staff Reports (1967, 1969), IMF Exchange Restrictions (1967), Malik (1990), New York Times (1987), Paris Club (2018), Walters (1970), World DataBank via Haver.

\section{El Salvador}

Beers and Chambers (2006), Das, Papaioannou and Trebesch (2012), Francis (2017), Paris Club (2018), World DataBank via Haver. 


\section{Equatorial Guinea}

IMF Article IV Staff Report (2005), Paris Club (2018), World DataBank via Haver.

\section{Eritrea}

World DataBank via Haver.

\section{Ethiopia}

Beers and Chambers (2006), Das, Papaioannou and Trebesch (2012), IMF (2016a), Paris

Club (2018), World Bank (2012), World DataBank via Haver.

\section{Fiji}

World DataBank via Haver.

\section{Gabon}

Beers and Chambers (2006), Cruces and Trebesch (2011), Das, Papaioannou and Trebesch (2012), Exotix (2011), Flynn and Pessoa (2014), IMF (2013d), Paris Club (2018), Rieffel (1985), World DataBank via Haver.

\section{Gambia}

Boughton (2001), Cruces and Trebesch (2011), Das, Papaioannou and Trebesch (2012), Flynn and Pessoa (2014), IMF Annual Reports (1985-86), IMF (2016a), Paris Club (2018), World DataBank via Haver.

\section{Georgia}

Authors' conversations with National Bank of Georgia staff, Das, Papaioannou and Trebesch (2012), Flynn and Pessoa (2014), Paris Club (2018), World DataBank via Haver.

\section{Ghana}

Beers and Chambers (2006), Bornschier, Pfister and Suter (1986), Das, Papaioannou and Trebesch (2012), Exotix (2011), IMF (2016a), IMF Article IV Staff Reports (1968-70), IFS via Haver, Krassowski (2014), Linzmayer (2016), Mas (1995), Paris Club (2018), Suter (1986), World DataBank via Haver. Note: Ghana’s local currency defaults in 1979 and 1982 were the result of confiscatory currency reforms.

\section{Greece}

FBPC (1965), Flynn and Pessoa (2014), IMF (2013b, 2013d, 2015a), Khan and Brunsden (2018), Zettelmeyer, Trebesch and Gulati (2013).

\section{Grenada}

Asonuma, Li and Papaioannou (2017), Beers and Chambers (2006), Bloomberg (2016), Cruces and Trebesch (2011), Das, Papaioannou and Trebesch (2012), Durant (2012), IMF (2013d), Paris Club (2018), Schipke, Cebotari and Thacker (2013), World DataBank via Haver.

\section{Guatemala}

Beers and Chambers (2006), Das, Papaioannou and Trebesch (2012), Exotix (2011), Paris Club (2018), World DataBank via Haver. 


\section{Guinea}

Cruces and Trebesch (2011), Das, Papaioannou and Trebesch (2012), IMF (2016a), IMF Article IV Staff Reports (1966-70), Paris Club (2018), World Bank (2012), World DataBank via Haver.

\section{Guinea-Bissau}

Das, Papaioannou and Trebesch (2012), IMF Article IV Staff Report (2014), Paris Club (2018), IMF (2016a), World DataBank via Haver.

\section{Guyana}

Boughton (2001), Cruces and Trebesch (2011), Das, Papaioannou and Trebesch (2012), IMF Annual Reports (1984-90), IMF (2016a), Paris Club (2018), World Bank (2012), World DataBank via Haver, World Development Report (1983).

\section{Haiti}

Boughton (2001), Das, Papaioannou and Trebesch (2012), IMF Annual Reports (1988-89, 1993-94), IMF Article IV Staff Reports (1961-70), IMF (2016a), Paris Club (2018), World Bank Financial Statement (2004), World DataBank via Haver.

\section{Honduras}

Boughton (2001), Cruces and Trebesch (2011), Das, Papaioannou and Trebesch (2012), IMF Annual Reports (1988-90), IMF (2016a), Paris Club (2018), World Bank (2012), World DataBank via Haver.

\section{Hungary}

CCBC (1976), FBPC (1976), World DataBank via Haver.

\section{India}

Bornschier, Pfister and Suter (1986), Suter (1986), World DataBank via Haver, World Development Report (1983).

\section{Indonesia}

Beers and Chambers (2006), Das, Papaioannou and Trebesch (2012), IMF Article IV Staff Reports (1966-70), Paris Club (2018), World DataBank via Haver.

\section{Iran}

Rieffel (2003), Suter (1992), World Bank (2013), World DataBank via Haver.

\section{Iraq}

Cruces and Trebesch (2011), Das, Papaioannou and Trebesch (2012), Exotix (2011), Ghabra (1991), IFS via Haver, IMF Annual Reports (1992-2003), IMF (2013a), IMF Article IV Staff Reports (2005-13), King (2004), Paris Club (2018), World Bank Financial Statements (2001-03, 2005), World DataBank via Haver. Note: World DataBank data on debt owed to other official creditors are not available prior to 2002. The 1990 local currency default stemmed from the actions of Iraq, then the occupying power in Kuwait, in converting Kuwaiti currency to Iraqi currency on confiscatory terms. The 1993 local currency default was the result of a confiscatory currency reform.

\section{Ireland}

European Commission (2013b), European Union (2013). 


\section{Jamaica}

Boughton (2001), Cruces and Trebesch (2011), Das, Papaioannou and Trebesch (2012), Durant (2012), Exotix (2011), Grigorian, Alleyne and Guerson (2012), IMF Annual Reports (1986-87), IMF Article IV Staff Report (2013), Paris Club (2018), Rieffel (1985), Schipke, Cebotari and Thacker (2013), World DataBank via Haver.

\section{Jordan}

Cruces and Trebesch (2011), Das, Papaioannou and Trebesch (2012), Paris Club (2018), World DataBank via Haver.

\section{Kazakhstan}

World DataBank via Haver.

\section{Kenya}

Cruces and Trebesch (2011), Das, Papaioannou and Trebesch (2012), Exotix (2011), Paris Club (2018), World DataBank via Haver.

\section{Korea (North)}

Alpert (2012), Exotix (2011), Haggard and Noland (2010), Hwang (2010), Linzmayer (2016), Paris Club (2018). Note: North Korea's local currency defaults in 1992 and 2009 were the result of confiscatory currency reforms. In the absence of central bank data, we utilize Hwang's assumption that currency in circulation amounted to 2 per cent of estimated GDP.

\section{Kyrgyzstan}

Das, Papaioannou and Trebesch (2012), Paris Club (2018), World DataBank via Haver.

\section{Laos}

IFS via Haver, IMF Staff Report (1979), World DataBank via Haver. Note: Laos’s 1976 local currency default was the result of a confiscatory currency reform.

\section{Lebanon}

World DataBank via Haver.

\section{Lesotho}

World DataBank via Haver.

\section{Liberia}

Boughton (2001), Bittermann (1973), Cruces and Trebesch (2011), Das, Papaioannou and Trebesch (2012), IMF Annual Reports (1985-2008), IMF Article IV Staff Reports (1964, 1969-70), IMF (2016b), Paris Club (2018), World Bank (2012), World Bank Financial Statements (2000-08), World DataBank via Haver.

\section{Macedonia}

Cruces and Trebesch (2011), Das, Papaioannou and Trebesch (2012), Exotix (2011), Paris Club (2018), Stanič (2001), World DataBank via Haver. 


\section{Madagascar}

Beers and Chambers (2006), Cruces and Trebesch (2011), Das, Papaioannou and Trebesch (2012), The Economist (2002), IFS via Haver, IMF (2005, 2016a), Paris Club (2018), Rieffel (1985), World DataBank via Haver.

\section{Malawi}

Cruces and Trebesch (2011), Das, Papaioannou and Trebesch (2012), Flynn and Pessoa (2014), IMF (2016a), Paris Club (2018), Rieffel (1985), World DataBank via Haver.

\section{Maldives}

World DataBank via Haver.

\section{Mali}

Das, Papaioannou and Trebesch (2012), IMF Article IV Staff Reports (1965-79), IMF (2016a), Paris Club (2018), World DataBank via Haver.

\section{Mauritania}

Cruces and Trebesch (2011), Das, Papaioannou and Trebesch (2012), IMF (2016a), Paris Club (2018), World Bank (2012), World DataBank via Haver.

\section{Mauritius}

World DataBank via Haver.

\section{Mexico}

Beers and Chambers (2006), Cruces and Trebesch (2011), Das, Papaioannou and Trebesch (2012), Paris Club (2018), Rieffel (1985), World DataBank via Haver.

\section{Moldova}

Cruces and Trebesch (2011), Das, Papaioannou and Trebesch (2012), Paris Club (2018), World DataBank via Haver.

\section{Mongolia}

Beers and Chambers (2006), Exotix (2011), World DataBank via Haver.

\section{Montenegro}

World DataBank via Haver.

\section{Morocco}

Cruces and Trebesch (2011), Das, Papaioannou and Trebesch (2012), Paris Club (2018), Rieffel (1985), World DataBank via Haver.

\section{Mozambique}

Cruces and Trebesch (2011), Das, Papaioannou and Trebesch (2012), IMF (2016a), Kroll (2017), Paris Club (2018), Rieffel (1985), World Bank (2012), World DataBank via Haver. Note: The 1980 local currency default was the result of a confiscatory currency reform.

\section{Myanmar}

IMF (2016a), IFS via Haver, Linzmayer (2016), Mas (1995), Paris Club (2018), World Bank Financial Statements (2000, 2004, 2008-09), World DataBank via Haver. Note: The 1964, 1985 and 1987 local currency defaults were the result of confiscatory currency reforms. 


\section{Nauru}

Asian Development Bank (AsDB) Annual Reports (2001-08), Firebird Global Master Fund II Ltd. v. Republic of Nauru (2012), Mellor (2014), Pacific Islands Report (2003).

\section{Nepal}

World DataBank via Haver.

\section{Nicaragua}

Boughton (2001), Cruces and Trebesch (2011), Das, Papaioannou and Trebesch (2012), Exotix (2011), IMF Annual Reports (1984-85), IMF (2007), IFS via Haver, IMF (2016a), Mas (1995), Paris Club (2018), World Bank (2012), World DataBank via Haver. Note: Nicaragua's 1988 local currency default was the result of a confiscatory currency reform.

\section{Niger}

Beers and Chambers (2006), Cruces and Trebesch (2011), Das, Papaioannou and Trebesch (2012), Flynn and Pessoa (2014), IMF (2016a), Paris Club (2018), World Bank (2012), World DataBank via Haver.

\section{Nigeria}

Cruces and Trebesch (2011), Das, Papaioannou and Trebesch (2012), Flynn and Pessoa (2014), IFS via Haver, Mas (1995), Paris Club (2018), World DataBank via Haver. Note: Nigeria's local currency defaults in 1967 and 1984 were the result of confiscatory currency reforms.

\section{Pakistan}

Bittermann (1973), Cruces and Trebesch (2011), Das, Papaioannou and Trebesch (2012), IMF Article IV Staff Report (1961), Paris Club (2018), Sturzenegger and Zettelmeyer (2005), World DataBank via Haver.

\section{Panama}

Beers and Chambers (2006), Boughton (2001), Cruces and Trebesch (2011), Das, Papaioannou and Trebesch (2012), IMF Annual Reports (1988-92), IMF (2013a), Paris Club (2018), World DataBank via Haver.

\section{Papua New Guinea}

World DataBank via Haver.

\section{Paraguay}

Beers and Chambers (2006), Cruces and Trebesch (2011), World DataBank via Haver.

\section{Peru}

Bittermann (1973), Bornschier, Pfister and Suter (1986), Boughton (2001), Cruces and Trebesch (2011), Das, Papaioannou and Trebesch (2012), Duggar and Leos (2015), IMF Annual Reports (1985-93), IMF Article IV Staff Reports (1969-71), IMF (2013a), Paris Club (2018), Schipani and Wigglesworth (2015), World DataBank via Haver, World Development Report (1983). Note: Local currency debt refers to domestic bonds that have been in default since the 1980s. Estimated amounts reflect an original face value of US\$343 million (as cited by Duggar and Leos) that over time has been impaired by exchange 
rate depreciation. The government acknowledges this debt, but amounts owing are in dispute with creditors and subject to domestic and foreign litigation.

\section{Philippines}

Cruces and Trebesch (2011), Das, Papaioannou and Trebesch (2012), Paris Club (2018),

Rieffel (1985), World DataBank via Haver, World Development Report (1981).

\section{Poland}

Cruces and Trebesch (2011), Das, Papaioannou and Trebesch (2012), Diwan and Saldanha (1991), FBPC (1976), Paris Club (2018), Rieffel (1985), World DataBank via Haver.

\section{Portugal}

European Commission (2013c), European Union (2013), Flynn and Pessoa (2014).

\section{Puerto Rico}

Chari, Leary and Phan (2018), Government of Puerto Rico (2017), Hitchcock, Petek and Aldrete-Sanchez (2015), Kaske and Sivaloganathan (2016). Note: Bonds in default refer to "tax supported" obligations, meaning that they are a claim on government tax revenues.

\section{Romania}

Boughton (2001), Cruces and Trebesch (2011), CCFB (1976), Das, Papaioannou and Trebesch (2012), Diwan and Saldanha (1991), Flynn and Pessoa (2014), FBPC (1979), IMF Annual Report (1986), IMF (2013a), Paris Club (2018), Rieffel (1985), World DataBank via Haver.

\section{Rwanda}

Das, Papaioannou and Trebesch (2012), IFS via Haver, IMF (2016a), Mas (1995), Paris Club (2018), World DataBank via Haver. Note: The 1995 local currency default was the result of a confiscatory currency reform.

\section{St. Kitts \& Nevis}

Durant (2012), IMF (2013e), IMF Article IV Staff Reports (2001-14), Paris Club (2018), Schipke, Cebotari and Thacker (2013), World DataBank via Haver.

\section{St. Lucia}

World DataBank via Haver.

108. St. Vincent and the Grenadines

World DataBank via Haver.

\section{Samoa}

World Bank Financial Statement (2007), World DataBank via Haver.

\section{São Tomé and Príncipe}

Cruces and Trebesch (2011), Das, Papaioannou and Trebesch (2012), IMF (2016a), Paris Club (2018), World Bank (2012), World DataBank via Haver. 


\section{Senegal}

Beers and Chambers (2006), Cruces and Trebesch (2011), Das, Papaioannou and Trebesch (2012), Exotix (2011), IMF (2016a), Paris Club (2018), World Bank (2012), World

DataBank via Haver.

\section{Serbia}

Cruces and Trebesch (2011), Das, Papaioannou and Trebesch (2012), Exotix (2011), IMF Annual Reports (1993-2000), Paris Club (2018), Stanič (2001), World Bank Financial Statements (2001, 2006), World DataBank via Haver.

\section{Seychelles}

Cruces and Trebesch (2011), Das, Papaioannou and Trebesch (2012), Exotix (2011), Flynn and Pessoa (2014), IMF (2013d), Paris Club (2018), Schipke, Cebotari and Thacker (2013), World Bank Financial Statements (2003-07), World DataBank via Haver.

\section{Sierra Leone}

Boughton (2001), Cruces and Trebesch (2011), Das, Papaioannou and Trebesch (2012), IMF Annual Reports (1985-94), IMF (2016a), Paris Club (2018), Rieffel (1985), World Bank (2012), World DataBank via Haver.

\section{Slovenia}

Beers and Chambers (2006), Cruces and Trebesch (2011), Stanič (2001).

\section{Solomon Islands}

AsDB SDBS (2017), IFS via Haver, IMF Article IV Staff Reports (2004-11), World

DataBank via Haver.

\section{Somalia}

Boughton (2001), Das, Papaioannou and Trebesch (2012), IMF Annual Reports (1985-2017), IMF (2013a), IMF (2016a), IMF Article IV Staff Report (2017), Paris Club (2018), Word Bank Financial Statements (2000, 2004, 2008-09), World DataBank via Haver.

\section{South Africa}

Beers and Chambers (2006), Cruces and Trebesch (2011).

\section{South Sudan}

IMF Article IV Staff Report (2017).

\section{Sri Lanka}

CBSL (1996), Das, Papaioannou and Trebesch (2012), IFS via Haver, IMF (2001), Paris Club (2018), World DataBank via Haver. Note: The 1996 local currency default reflects the suspension of treasury bill auctions and rollover of maturing debt between January and March after the central bank was severely damaged by a terrorist bomb.

\section{Sudan}

Boughton (2001), Cruces and Trebesch (2011), Das, Papaioannou and Trebesch (2012), Exotix (2011), IFS via Haver, IMF Annual Reports (1984-2017), IMF (2013d, 2016a), IMF Article IV Staff Report (2017), Mas (1995), Paris Club (2018), Rieffel (1985), World Bank Financial Statements (2000, 2004, 2008-09), World DataBank via Haver. For revisions to 
official creditor data, see footnote 4. Note: Sudan's local currency default in 1991 was the result of a confiscatory currency reform.

\section{Suriname}

Beers and Chambers (2006), IMF Article IV Staff Reports (2003-14), World DataBank via Haver.

\section{Swaziland}

World DataBank via Haver.

\section{Syria}

IMF Article IV Staff Report (1965), Paris Club (2018), World Bank Financial Statements (2001-02), World DataBank via Haver.

\section{Tajikistan}

World DataBank via Haver.

\section{Tanzania}

Boughton (2001), Cruces and Trebesch (2011), Das, Papaioannou and Trebesch (2012), Exotix (2011), IMF Annual Reports (1985-86), IMF (2016a, 2016c), Paris Club (2018), World Bank (2012), World DataBank via Haver.

\section{Thailand}

World DataBank via Haver.

\section{Togo}

Cruces and Trebesch (2011), Das, Papaioannou and Trebesch (2012), IMF (2016a), Paris Club (2018), Rieffel (1985), World Bank Financial Statements (2004, 2008), World Bank (2012), World DataBank via Haver, World Development Report (1983).

\section{Tonga}

World DataBank via Haver.

\section{Trinidad \& Tobago}

Cruces and Trebesch (2011), Das, Papaioannou and Trebesch (2012), Paris Club (2018).

\section{Tunisia}

World DataBank via Haver.

\section{Turkey}

Bornschier, Pfister and Suter (1986), Cruces and Trebesch (2011), Das, Papaioannou and Trebesch (2012), Ferris (2011), IFS via Haver, IMF Article IV Staff Reports (1966, 2000), Paris Club (2018), Rieffel (1985), Tudela (2011), World DataBank via Haver. Note: Turkey’s 1999 local currency debt default reflected the imposition of a withholding tax targeting government securities issued prior to December of that year.

\section{Turkmenistan}

World DataBank via Haver. 


\section{Uganda}

Cruces and Trebesch (2011), Das, Papaioannou and Trebesch (2012), Exotix (2011), Flynn and Pessoa (2014), IMF (2016a), Paris Club (2018), Rieffel (1985), World Bank (2012), World DataBank via Haver.

\section{Ukraine}

Beers and Chambers (2006), Cruces and Trebesch (2011), Das, Papaioannou and Trebesch (2012), Exotix (2011), IMF (2015b), Olearchyk (2015), Paris Club (2018), Sturzenegger and Zettelmeyer (2005), Ukraine (2014), World DataBank via Haver.

\section{Uruguay}

Bittermann (1973), Cruces and Trebesch (2011), IMF Article IV Staff Report (1966), Sturzenegger and Zettelmeyer (2005).

\section{USSR/Russia}

Beers and Chambers (2006), Cruces and Trebesch (2011), Das, Papaioannou and Trebesch (2012), Diwan and Saldanha (1991), Ferguson and Granville (2000), IFS via Haver, Mas (1995), Paris Club (2018), Shpakovsky (2013), Sturzenegger and Zettelmeyer (2005), World DataBank via Haver. Note: The 1991 and 1993 local currency defaults were the result of confiscatory currency reforms.

\section{Uzbekistan}

World DataBank via Haver.

\section{Vanuatu}

World DataBank via Haver.

\section{Venezuela}

Banco Central de Venezuela (2017), Beers and Chambers (2006), Cruces and Trebesch (2011), Culverhouse (2018), Exotix (2011), Foy, Rathbone and Allen (2017), IFS via Haver, Martin (2017), Tudela (2011), World DataBank via Haver. Note: Venezuela’s 2016 local currency default was the result of a confiscatory currency reform.

\section{Vietnam}

Boughton (2001), Cruces and Trebesch (2011), Das, Papaioannou and Trebesch (2012), Exotix (2011), IFS via Haver, IMF Annual Reports (1984-93), IMF Article IV Staff Report (1989), Mas (1995), Paris Club (2018), World DataBank via Haver. Note: Vietnam's 1975 local currency default resulted from the conversion of South Vietnamese currency to North Vietnamese currency on confiscatory terms. The 1978 and 1985 local currency defaults were the result of confiscatory currency reforms. As central bank records are not available for 1978, currency data for Laos, with comparable per capita US-dollar GDP, was used to calculate a proxy value for converted Vietnamese currency.

\section{Yemen}

Cruces and Trebesch (2011), Das, Papaioannou and Trebesch (2012), Paris Club (2018), World Bank (2012), World DataBank via Haver.

\section{Yugoslavia}

Beers and Chambers (2006), Cruces and Trebesch (2011), Das, Papaioannou and Trebesch (2012), IMF Article IV Staff Reports (1965-69), Paris Club (2018), Stanič (2001), World DataBank via Haver. 


\section{Zambia}

Boughton (2001), Cruces and Trebesch (2011), Das, Papaioannou and Trebesch (2012), IMF Annual Reports (1985-95), IMF (2016a), Paris Club (2018), Rieffel (1985), World Bank (2012), World DataBank via Haver.

\section{Zimbabwe}

Corporation of Foreign Bondholders (1981), IMF Annual Reports (2001-17), Makoshori (2015), Paris Club (2018), Republic of Zimbabwe (2015), World Bank Financial Statements (2001-17), World DataBank via Haver. Note: Foreign currency bonds in default since 2009 reflect obligations owed to mining companies by the Reserve Bank that were assumed by the government in 2015 . 